\title{
Development of agritourism in Poland: a critical analysis of students' expectations of agritourism farms
}

\begin{abstract}
The aim of this paper is to determine the expectations of students from selected Polish academic centers toward facilities at agritourist farms, and identifying the socio-demographic characteristics that determined those expectations. A survey method was used in this research. Using the Likert's five-level scale, respondents rated the significance of elements of agritourist farm facilities. It was found that academic youth expected, above all, facilities for enabling passive leisure and the independent preparation of meals. Provision of facilities for active leisure were of less significance to them. Gender, place of living, field of study and prior experience connected to leisure on the farms analyzed were not factors that differentiated students' expectations. A weak correlation was found between students' expectations of facilities at agritourist farms and their economic status. Students' expectations were very similar to the expectations of the average agritourist. Research results confirmed some of the results known from the literature, stating that socio-demographic characteristics differentiated the expectations of academic youth to a small extent. However, the effects obtained did not correspond to results claiming that age, gender, place of living and income have a significant influence on tourist expectations. Additionally psychographic characteristics should be considered in the following research. A combination of demographic and psychographic characteristics may offer a wider base for analysis and give better end results, allowing market segmentation.
\end{abstract}

Keywords

Agritourist farms $\cdot$ expectations $\cdot$ academic youth

(C) University of Warsaw - Faculty of Geography and Regional Studies

Introduction

The process of political transformation in Poland, initiated at the end of the last century, constrained changes in the functioning of all sectors of the national economy, economic entities and administrative units. Competitiveness; understood as the ability of enterprises, industries, regions and states to generate relatively high incomes (Globalisation and Competitiveness... 1996) and to provide their inhabitants with a high and improving standard of living (European Competitiveness... 2001); has become the basis of their functioning. The transformation resulted in intersectoral relationship changes in the national economy expressed by, among other things, a significant decrease in agriculture (BaerNawrocka \& Poczta 2014). According to the cited authors, between the years 1989 and 2012 the share of agricultural global output plummeted from $14.6 \%$ to $4.1 \%$, while GDP fell from $11.8 \%$ to $3.5 \%$, and capital expenditure from $12.8 \%$ to $1.9 \%$. In 2012 , agricultural workers still totaled around $13 \%$ of the working population in Poland while in the analogous EU-15 index they accounted for around $3 \%, 3 \%$ in the Czech Republic, $7 \%$ in Bulgaria, $5 \%$ in Hungary, $8 \%$ in Lithuania and almost $10 \%$ in Latvia (Frenkel 2014). This means that the relationship between the above mentioned indicators (e.g. employment and GDP) in Poland was disadvantageous and evidenced limited capacity for equalizing the standard of living for people living in the countryside and those living in cities.

\author{
Wioletta Kamińska, \\ Mirosław Mularczyk \\ Institute of Geography \\ Jan Kochanowski University in Kielce \\ Poland \\ e-mail: wioletta.kaminska@ujk.edu.pl \\ e-mail: miroslaw.mularczyk@ujk.edu.pl \\ Received: 1 June 2015
}

Accepted: 27 October 2015

Due to the disadvantageous economic situation in rural areas of the country, a multifunctional development concept was preferred from the very beginning of the transformation process. An efficient integration of non-agricultural functions into rural space was the basis of this concept (Kłodziński 1997). An entrepreneurial development was promoted in both agricultural holdings and beyond.

According to the Agricultural Census (2002) almost 9\% of agricultural holdings conducted both agricultural and nonagricultural activities, and around $3 \%$ of holdings operated only in non-agricultural businesses. As of the 1990s, agritourism can be found among the additional activities that diversify the income sources of agricultural holdings. In the specialist literature (see e.g. Gurgul 2005) a predominant view arose that with the limited possibilities for selling crops, high unemployment and relatively low standard of living of rural inhabitants, agritourism could pose a chance to improve the economic situation of rural areas. Privitera (2010), and Kumbhar (2012) claimed that agritourist development might strengthen local economies, create new workplaces and possibilities for setting up new companies, develop and promote training, and create programs that would initiate young people in agriculture and environment. Brown and Reeder (2007) proved that agritourism is a way of diversifying and increasing the income of inhabitants of rural areas. Moreover, research 
shows that agritourism is a mechanism for stimulating rural area development, increasing the standard of living of inhabitants of rural areas by stimulating farmers' activities (Tew \& Barbiere 2012), promoting and creating added value (Zoto et al. 2013) and maintaining unique culture characteristics (Ollenburg \& Buckly 2007; Maneenetr \& Tran 2014).

It was estimated that in the United States, income generated by agritourism accounts for between 800 million and 3 billion USD a year (Carpio et al. 2008). In California alone in 2008 agritourist farms were visited by 2.4 million tourists (Rilla et al. 2011). As the cited authors claim; during this period the income of more than a half the farmers that had agritourism farms exceeded 50 thousand USD. Data regarding agritourism in Australia (Bondoc 2009), Canada (Ainley \& Smale 2010), Italy (Ohe \& Ciani 2012) and Japan (Ohe 2008) are equally optimistic.

However, Polish research showed that the profitability of agritourist services was diverse. According to Broniec and Serocka (2005) income from agritourism accounted for one-third of rural holdings' profits. Woźniak and Kuźniar (2000) estimated it at a similar level. In Jalnik's (2005) view; however, this income could have even amounted to half of agricultural holdings' profits. Nevertheless, there was a second group of researchers (see Wiśniewska 2008; Sosnowski, Ciepiela \& Jankowski 2008; Cichowska 2010) who stated that, indeed, income from agritourism has been rising on a year on year basis (Kryński et al. 2006), but globally it was still small (Sadowski 2004). Lack of promotion, low innovativeness, not using modern forms of communication with potential clients, and a limited market for these kinds of services were pointed out as the reasons for the low profitability of agritourism in Poland. From the beginning of the functioning of agritourist farms, what they offered was directed at a specific group of clients. They were, most frequently, big city inhabitants, families with small children, and people with limited financial resources. The owners of agritourist farms practically did not look for new social groups to which they could present their agritourist services. The research done by this paper's authors (Kamińska \& Mularczyk 2014) shows that students could be interested in the agritourist services market. It is a large social group: in 2013 academic youth accounted for almost $5 \%$ of Polish society.

Currently there are around 10 thousand agritourist farms functioning in Poland (Rudnicki \& Biczkowski 2015). Their degree of utilization is diverse. Kamińska and Mularczyk (2014) stated that in 2013 the degree of utilization of agritourist quarters (a facility that has 10 and more rooms) amounted to only $11 \%$, which in relation to 2002 was 3 pp lower. This means that broadening what is offered to the agritourist and client target groups should be a basic marketing target.

Orientating services to attract the new social group requires prior, reliable research on students' expectations regarding agritourism. Until now no such research has been conducted in Poland even though understanding tourists' expectations is the most important element in marketing (Carpio et al. 2008). Knowing academic youth's expectations and preferences regarding tourism will allow adjustment of what is on offer in order to suit this client target group's needs (Clarke 1999; Gunn 1994; Speirs 2003), elaborating new programs in agritourist farm development and adjusting its promotion to a level demanded by students (Heung et al. 2001). Knowing the decisions of this social group regarding tourist destination choices, will constitute a market advantage for agritourist farmers as they will have the advantage of predicting and anticipating destinations as well as the activities in which tourists (including students) want to participate. Such an approach would produce better market segmentation and influence promotion strategy quality (Cha et al. 1995; Speirs 2003; Wilson 2007). Tourist business success depends on providing services in accordance with tourist's expectations
(Kumbhar 2012). It should also be underlined that knowing the expectations of tourists allows for better use of the farm's market possibilities (Keng \& Cheng 1999) and optimization of market expenses (Speirs 2003). A strategy based on knowledge usually gives better results (Vanhove 1994), and agritourist farmers could direct their efforts toward desired outcomes and adapt the existing product to the chosen group's requirements (Perreault et al. 1977; Vanhove 1994; Speirs 2003). Maladjustment of supply and demand is an important factor in limiting the degree of participation in tourism and recreation (Hoffman 1980). Research also showed that the more businesses know about their clients, their expectations and their needs, the better it can develop appropriate services and the better the company functions (Oh \& Schuett 2010; Park \& Yoon 2009).

So far, in the scientific literature, broad research into the expectations of academic youth regarding agritourism has not been done. It was assumed a priori that it is not an area of tourism directed at this social group. However, it is worth observing this group in terms of marketing. Research shows (Latosińska \& Ludwicka 2010; Lubowiecki-Vikuk \& Podgórski 2013) that more than $80 \%$ of academic youth took part in tourist activity, and interest in tourism occupied a high position in the hierarchy of this group's interests (Brojek \& Bochenek 2012). The research also confirmed that students often carried out adventure tourism activities (bike riding, water sports, hiking, winter sports). Consequently, one may claim that the students' above mentioned touristic preferences can be satisfied by agritourism. Additionally, the lower price of leisure (compared to hotels) on agritourist farms corresponds with the financial capacity of academic youth.

In the light of the above statements, the aim of this paper is to present preliminary research results that leads to determining the expectations of students from selected academic centers in Poland toward agritourist farms and the identification of sociodemographic characteristics that determine those expectations. Specific objectives were formulated using the following questions:

1. What were the surveyed academic youths' expectations of the agritourist farm facilities?

2. Were the above mentioned expectations diversified according to the gender of the surveyed students?

3. Was the financial situation of the surveyed students, calculated as net income per one family member, a factor in diversifying the above expectations?

4. Were the surveyed students' place of living a characteristic that shaped different expectations regarding agritourist farm facilities?

5. Were the surveyed students' expectations diversified according to their field of study?

6. Were the surveyed students' expectations regarding agritourist farms dependent on earlier experiences with using such services?

The answers to the above questions may help the owners of agritourist farms to adjust and broaden what they offer, acquire new clients and prepare a new development and promotion strategy for their services.

It was assumed in the paper that expectations are understood as supposition, hope, and need; as something one needs and expects (Słownik Języka Polskiego; Polish Dictionary 2013).

\section{Research methods}

A survey method was used in this research. The survey was conducted in January and February of 2015 on a sample of 639 students from selected Polish institutions of higher education. The research was preliminary and was a part of a larger research project that concerns the tourist activity of academic youth in Poland. The survey was conducted on 
students from four institutions of higher education of university character (two with a solid reputation: Warsaw University and Maria Curie-Skłodowska University. Two with short university traditions: Jan Kochanowski University in Kielce, and Kazimierz Pulaski University of Technology and Humanities in Radom. And one higher vocational school: The Bronisław Markiewicz State Higher School of Technology and Economics in Jarosław). The questionnaire concerned the expectations of academic youth toward agritourist farm facilities. Respondents were asked to rate the significance ascribed to sixteen facilities. A 5-level Likert scale was used where 0 means no significance, 1 a small significance, 2 a medium significance, 3 a great significance and 4 a very great significance. Moreover, respondents could describe their expectations for facilities for agritourist farms that were not on the questionnaire list.

In the gender structure of the respondents, women were in the majority, accounting for over $68 \%$ of the whole researched group (Fig. 1). The analysis of place of living of the researched group; however, indicated that most people were coming from villages (more than half), rather than from a big city (of over 100 thousand inhabitants) - more than $20 \%$. Almost $26 \%$ of the respondents were permanently registered in small and medium urban centers (up to 20 thousand inhabitants and from 20 to 100 thousand inhabitants). Students represented different academic centers and different fields of study. The majority of students were receiving their education in Kielce: they amounted to more than half of respondents. Almost one in six respondents studied in Lublin, one in seven in Warsaw while $10 \%$ were students from Radom, and $4 \%$ from Jarosław.

Almost one third of respondents were studying Tourism and Recreation, one quarter Geography and one fifth National Security. Administration students accounted for more than $15 \%$ and students of Spatial Planning around 5\%.

The vast majority of students declared that the net income per one family member was low (up to 1 thousand zloty) or medium (from 1 to 2 thousand zloty). More than $73 \%$ of respondents chose these answers. The net income level per one person was on a high level (from 2 to 4 thousand zloty) in the families of one in every five students, and just over $7 \%$ of respondents described it as very high (over 4 thousand zloty).

Basic statistical indicators such as average and standard deviation, were used in this research. The results were presented using a graphic method, mainly radar charts.

\section{Research on tourists' expectations}

Research on tourists' expectations serves as a basis for creating a touristic product and the development of a whole branch of tourism. Fulfilment of these expectations is not only the reason for tourists' satisfaction, but also guarantees promotion of tourist services and tourist areas (Carpio et al. 2008; Wilson 2007; Kumbhar 2012). Recognition of consumers' expectations regarding the touristic product being offered, as well as the characteristics preferred in determining the choice of the product, facilitates the product's improvement, refinement of its parameters, and providing the most wanted characteristics (Szymańska \& Dziedzic 2005). As the cited authors claim; the consumer's expectations are a source of inspiration for the enterprise, and allow to it to verify its marketing decisions made during all phases of shaping what is on offer to the tourist.

It is not surprising that research on the expectations of tourists has an established position in the science world. Papers on this matter have studied almost all subjective and objective segments of the tourist market.

Research on tourists' expectations regarding the tourist market, separated on the basis of geographic criteria (see: Walesiak 2000; Kumbhar 2012) was done by, among others,

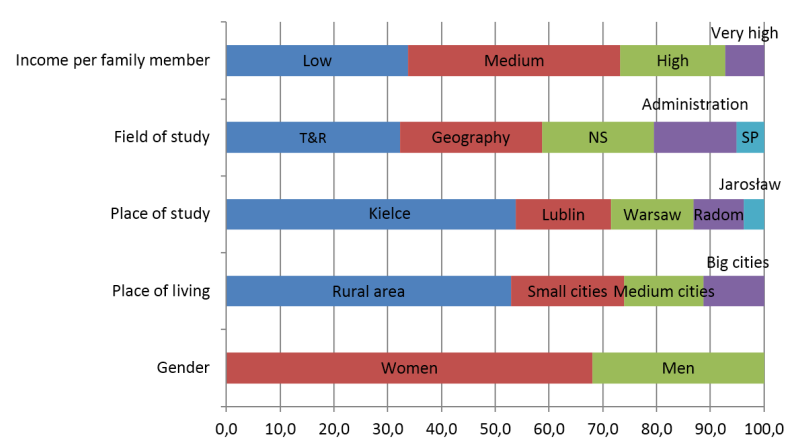

Figure 1. Respondents structure by socio-demographic characteristics. NS - National Security, SP - Spatial Planning, T\&R - Tourism and Recreation.

Source: own research

Morrison et al. (1996), Heung et al. (2001), Maetzold (2002), Campiranon (2008), Mikos von Rohrscheidt (2014), Rilla et al. (2011), Szpilko et al. (2013). The authors paid attention to the diversified expectations of chosen cities' inhabitants (Szpilko et al. 2013), foreign tourists (Alejziak 1991; Baloglu 1997; Carpio et al. 2008; Ainley \& Smale 2010; Rilla et al. 2011), and the inhabitants of cities and rural areas (Kastenholz et al. 1999; Balińska 2014).

Tourists' expectations of the tourist market separated on the basis of demographic criteria were the subject of studies by, among others, Woodside, Pitts (1976), Vanhove (1994), Teaff, Turpin (1996), Kastenholz (1999), Bondoc (2009), Nasers (2009), Łaciak (2013). The results of these studies were equivocal.

On the one hand, for example, Cha et al. (1995), Formica, Uysal (1998), and Heung et al. (2001) proved that the expectations of tourists varied greatly depending on gender, age, and family size, but also due to the phase of its development. Keyser (2002) underlined that age determines both the amount of time spent on leisure as well as people's inclination to travel. The main tourist activity happens before a person reaches 40 and decreases with age, but the pace of this fall-off is different for each gender (Unkle 1981; Hartman \& Cordel 1989). The declining frequency of participation in recreation and tourist trips is visible earlier in the case of women than in men (Robinson 1967). At the same time, the reduced physical abilities of the elderly limit the choice of holiday destination and activities (Kattiyapornpong et al. 2009). Jefferson (1991) has found that young people (up to 25 years old) choose longer rest periods and stay at tourist destinations longer than the average tourist. Speirs's (2003) study regarding gender influence on tourist behavior shows that women, more often than men, travel as tourists.

A theory that the life cycle of a family was one of the most important elements in creating behaviors and tourist expectations is present in many studies. For example Witt and Goodale (1981) stated that couples with small children dispose of less amount of time for tourist activity than in other phases of the cycle. Carpio et al. (2008) proved a positive relation between families with small children and visits to agritourist farms. Authors explained this fact as parents seeing this kind of recreation as sustainable for children and families. Hall's (1973) research shows that women's share in recreational activity drops quickly after getting married, and having kids makes this decrease even faster.

On the other hand, the view that demographic characteristics cannot be a base for good tourist market segmentation is also visible in the literature (Woodside \& Pitts 1976; Cheng \& Lio 2001; Plummer 1974). Lawson (1994) observed that people with similar demographic characteristics did not necessarily have the same touristic interests. Keng and Cheng (1999) claimed that it is better to use psychographic characteristics (including psychological characteristics and lifestyle) to study the behaviors and tourists' 
expectations of people. These characteristics reflect the degree and the kind of touristic and recreational activities, interests, opinions, personality and standards of living (Plummer 1974; Nickerson 1996; Blackwell et al. 2001). They also influence imagination and the perception of tourist's experiences (Ashworth \& Goodwall 1998; Speirs 2003).

Tourists' expectations were also differentiated according to their socioeconomic characteristics (income, education, occupation, social class).

Research results are diverse in this case as well (Hartman \& Cordell 1989). Economic concepts assume that when the income of a particular person rises, their demand for trips most likely rises as well (Wang et al. 2006). However, O'Leary et al. (1982) proved that income does not determine tourist behaviors and expectations. Income does not form tastes but rather limits their expression. And Hartman and Cordell (1989), based on literature review, claimed that people with high income stay in a place of rest longer than the average tourist, and that travelling distance rises for the group with high income. Nevertheless, other factors such as age can influence travelling distance. Nicolau and Más (2005) stated that income, household size and the level of education are determinants influencing tourists' decisions and expectations. A higher income increased the probability of planning another trip (Kattiyapornpong et al. 2009).

Cha, McCleary, Uysal (1995) indicated that the level of education was an important factor in influencing tourists' motivations and expectations. According to these authors, people travel because they are "pushed" by their internal needs and "pulled" by tourist destination attributes. The strengthening of those factors is connected with knowledge and level of education. Zuzanek (1978, cit. after Hartman \& Cordell 1989) stated that the index of participation in relaxation and recreation rises almost linearly with an increase in education level. Peak recreation participation is noticeable among people with the highest education; however, some activities are not positively correlated with education. Catalino (et al. 2004) claimed that the level of education had the highest influence on tourist expectations out of all demographic and economic characteristics.

The view that a positive correlation between tourist's expectations and white collar occupations exists, can be found in the literature. Zuzanek (1978), based on the literature, stated that participation in relaxation is highly and positively correlated with social status and occupational prestige. According to the author, white collar workers participate in a wider spectrum of tourist activities and at least some of them require a relevant occupational status (Zuzanek 1978; after: Hartman \& Cordel 1989).

A whole series of papers dealing with the determination of tourists' expectations toward agritourism can be found in Western literature. Preferences in choices of agritourist destination (Maetzold 2002), towns' public transport availability (Srikatanyoo \& Campiranon, 2008) and the geographic environmental characteristics where agritourist farms were located (Agri-tourism in Southern Scotland, 2011) were researched. Some of the authors noted the level of tourist services (Cunningham \& Sagas 2006; Chi et al. 2010; Kumbhar 2010) and the state of agritourist farm facilities and rented rooms (Bondoc 2009). The quality of the educational aspects of agritourism (Bouĉkova 2008, Kumbhar 2010) and tourists' expectations toward agritourist services such as sharing in field work (Bouĉkova 2008), the purchase of local food products (Chi et al. 2010; Kumbhar 2012), horseback riding (Bondoc 2009) etc., were underlined in many papers. These expectations were linked with demographic (Woodside, Pitts 1976; Carpio et al. 2008) and social (Kumbhar 2012) characteristics as well as the lifestyle (Zins 1998) of agritourists.

In the last few years, more research on tourists' expectations toward agritourism has appeared (Zawadka 2012, 2014; Wilk \& Keck-

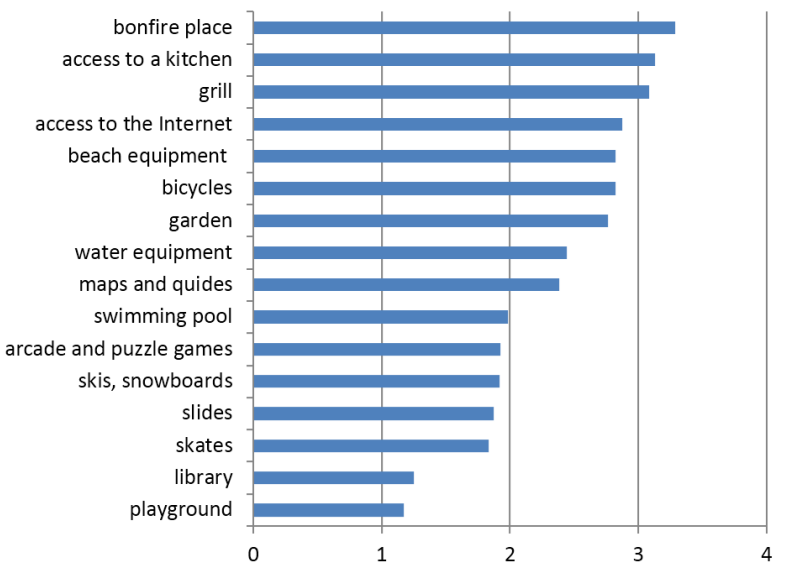

Figure 2. Students' expectations toward agritourist farm facilities Source: Own calculations

Wilk 2013). The research has shown that agritourists expected a diversified range of services, which should be prepared with regard to the individual needs of tourists (Wilk \& Keck-Wilk 2013). What is more, they wished for bicycles and water equipment rentals to be available on agritourist farms (Zawadka 2014), and rooms to be mandatorily equipped with a bathroom (Zawadka 2012).

The expectations of academic youth toward agritourist farm facilities

Agritourism offers new types of satisfaction for the tourist; that is: modest accommodation, physical activity, participation in rural activities and a closeness to nature (Gilbert 1989). The agritourist does not usually expect high-quality accommodation (Kumbhar 2010), but needs a basic set of facilities that are necessary for active and passive leisure as well as daily functioning connected with food preparation and communication with others (i.e. access to the Internet) (Zawadka 2014).

The conducted survey research found that in students expectations, the most important were: a bonfire place (average value on Likert's scale, for all respondents was 3.29), access to a kitchen (3.13) and a the possibility of using a grill (3.08) (Fig. 2 ). The bonfire place was of great or very great significance for almost $87 \%$ of respondents, while access to a kitchen was $80 \%$ and the grill $78 \%$ (Tab. 1).

Access to the Internet (2.87 on Likert's scale), provisions for beach equipment (2.82), bicycles (2.82) as well as a garden (2.76) were not much less significant for respondents' rest at agritourist farms: they were of great and very great importance to around $65 \%$ of surveyed students (Fig. 2, Tab. 1).

The survey results presented above show that students were intending both passive leisure (in the garden, by the bonfire or grill) as well as active leisure (mostly riding bicycles). The possibility of enjoying water sports (water equipment was rated 2.44 on average for Likert's scale) was of less significance. The possibility for enjoying winter sports was even less important. The farms' facilities for skis, snowboards, slides and skates was rated between 1.83 and 1.91 . This may indicate that students preferred agritourist vacations during the summer holidays. The significance of having a swimming pool (1.98), and puzzle and arcade games (1.9) was rated similarly by the respondents to having winter sports equipment. The surveyed students least expected a library (1.24) or a playground (1.17) (Fig 2.). The latter was of no significance for almost $40 \%$ of respondents, whereas $31 \%$ indicated a library was needless (Tab. 1). The provision of maps and guides, enabling students to familiarize themselves 
MISCELLANEA GEOGRAPHICA - REGIONAL STUDIES ON DEVELOPMENT

Vol. $19 \cdot$ No. 4 • 2015 • pp. 44-55 • ISSN: 2084-6118 • DOI: 10.1515/mgrsd-2015-0023

Table 1. Significance of agritourist farm facilities for students

\begin{tabular}{|c|c|c|c|}
\hline \multirow{2}{*}{$\begin{array}{c}\text { agritourist farm } \\
\text { facilities }\end{array}$} & \multicolumn{3}{|c|}{ significance (\% of respondents) } \\
\cline { 2 - 4 } & $\begin{array}{c}\text { no } \\
\text { significance }\end{array}$ & $\begin{array}{c}\text { small and } \\
\text { medium }\end{array}$ & $\begin{array}{c}\text { great and } \\
\text { very great }\end{array}$ \\
\hline bonfire place & 0.8 & 12.4 & 86.8 \\
\hline access to a kitchen & 2.8 & 17.7 & 79.5 \\
\hline grill & 1.6 & 20.6 & 77.8 \\
\hline bicycles & 0 & 33.1 & 66.9 \\
\hline $\begin{array}{c}\text { access to the } \\
\text { Internet }\end{array}$ & 4.4 & 28.8 & 66.8 \\
\hline beach equipment & 3.6 & 30.8 & 65.6 \\
\hline garden & 5 & 30.2 & 64.8 \\
\hline maps and guides & 7.8 & 41 & 51.2 \\
\hline water equipment & 4.1 & 46.6 & 49.3 \\
\hline skis, snowboards & 17.7 & 47.1 & 35.2 \\
\hline pool & 12.4 & 56.2 & 31.4 \\
\hline slides & 15.2 & 53.9 & 30.9 \\
\hline arcade and puzzle & 13.9 & 57.6 & 28.5 \\
\hline games & 16 & 56 & 28 \\
\hline skates & 39.6 & 43.3 & 17.1 \\
\hline playground & 30.7 & 55.9 & 13.4 \\
\hline library & & & \\
\hline
\end{tabular}

Source: Own calculations

with the farms' neighborhood, was of only medium significance (2.38 on Likert's scale). What is more, additional elements of facilities were mentioned in few respondents' questionnaires. Those students claimed that, for them, a bike shed ( 5 people), a playing field (3), a gym (1), a parking spot (1) and sauna (1) played a significant role.

The above results do not fully correlate with the results of Polish researchers regarding tourists' expectations toward agritourist centers and are divergent when compared to analogous research conducted in other countries. According to Zawadka (2014), an average Polish tourist spending holidays on a farm valued quiet, peace and the beauty of nature. Thus they expected to be able to rent a bike for scenic rides, beach equipment, and access to a balcony and a garden. Access to a kitchen was also among the most wanted elements. Due to the fact that families with small children accounted for the majority of Polish agritourists, a playground was also a desired element of the farms' facilities. A bonfire place, grill and access to the Internet were less important in their expectations. This means that a set of basic agritourist farm facilities was similar in the opinion of both students and other tourists, and only particular elements were of a different significance in the hierarchy of their expectations.

Agritourists in western European countries and the USA presented higher demands of agritourist farm facilities (see: Carpio et al. 2008; Rilla et al. 2011), even though their preference for a quiet and rural environment was similar. The majority of those surveyed had their own bikes for scenic rides (Speirs 2003), yet they wanted to rent other equipment. As the cited author proved, agritourists were searching for adventure, but didn't try to buy appropriate equipment. Water skis, boats, windsurfing boards, skis and snowboards, hunting and hiking equipment were the

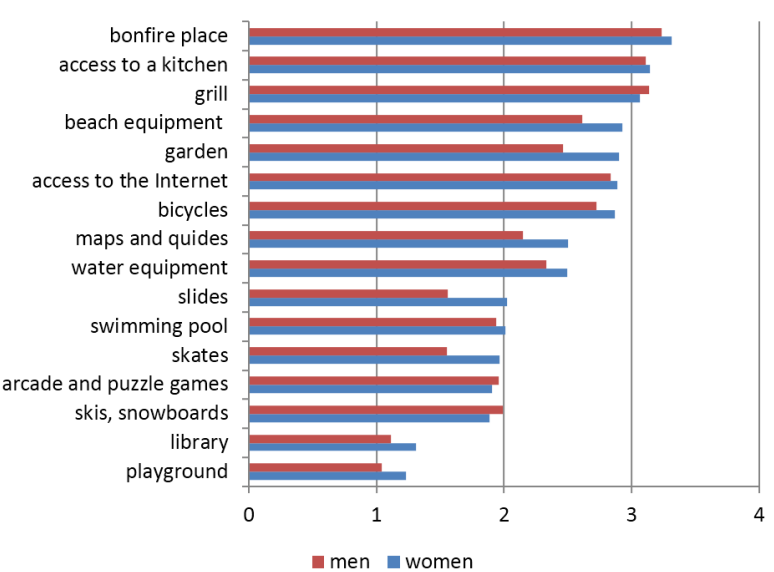

Figure 3. Diversity of expectations toward agritourist farms facilities by gender

Source: Own calculations

most expected pieces of facilities on agritourist farms. The high placing of winter sports equipment in the expectations structure was connected to the fact that in many countries the highest frequency of agritourism vacations during the entire year is noted in the winter season, when it is possible to ski and use other winter equipment (see: Ohe \& Ciani 2012). Polish students preferred holidays in rural areas during the summer holidays.

Students' expectations toward agritourist farm facilities regarding gender

The importance of gender as a relevant factor in the creation of tourist's expectations is often underlined in the research papers on this matter (Zuzanek 1978; Gentry \& Doering 1979; Teaff \& Turpin 1996; Lang et al. 1997). Study results show that women more often travel for tourist purposes (Speirs 2003) and men more often visit agritourist farms (Carpio et al. 2008). Women prefer less energyconsuming activities such as walking for pleasure, sunbathing, picnics, than men. On the other hand, men are more interested in horseback riding, hiking, hunting, fishing (Speirs 2003). Gentry and Doering underlined that the difference between women and men does not rely only on the kind of preferred activity, but also on both genders attitudes toward them.

Our research proved that gender was not an important determinant shaping the expectations of the students surveyed toward agritourist farm facilities. The conducted analyses indicates that the expectations of women and men toward agritourist farm facilities were similar (Fig. 3, Tab 2).

The average value of significance on Likert's scale for all facilities put forward in the survey was: in the case of women, 2.40; and in case of men 2.23. For both gender groups, the difference from the average for the whole (2.35) was smaller than the standard deviation (0.12), and that is why it should have been considered statistically insignificant. Nevertheless, detailed analyses of the values, on Likert's scale, for each of the elements of agritourist farm facilities indicated that most elements facilitating passive leisure, such as: garden (women: 2.9, men: 2.46), and beach equipment (women: 2.92, men: 2.61), and active leisure in the case of slides (women: 2.02, men: 1.56) and skates (women: 1.97, men: 1.55) were more important to women. Moreover, women's expectations of farms provisioned with maps and guides were higher than men's. The average value on Likert's scale for women was 2.50 whereas for men it was 2.15 (Fig. 3).

Therefore, results obtained do not relate to the results of similar research in which such a correlation was stated (Zuzanek 
Table 2. Significance of agritourist farm facilities for students by gender

\begin{tabular}{|c|c|c|c|c|c|c|}
\hline \multirow{3}{*}{ agritourist farm facilities } & \multicolumn{6}{|c|}{ significance ( $\%$ of respondents) } \\
\hline & \multicolumn{2}{|c|}{ no significance } & \multicolumn{2}{|c|}{ small and medium } & \multicolumn{2}{|c|}{ great and very great } \\
\hline & women & men & women & men & women & men \\
\hline bonfire place & 0.9 & 0.5 & 10.8 & 15.7 & 88.3 & 83.9 \\
\hline access to a kitchen & 3.2 & 2 & 16.1 & 21 & 80.7 & 77 \\
\hline grill & 3.7 & 5.9 & 29.4 & 27.4 & 66.9 & 66.7 \\
\hline bicycles & 3.2 & 4.4 & 27.8 & 37.3 & 69 & 58.4 \\
\hline access to the Internet & 1.8 & 1 & 20.4 & 21.1 & 77.7 & 77.9 \\
\hline beach equipment & 3.4 & 8.3 & 26.9 & 37.2 & 69.7 & 54.4 \\
\hline garden & 1.4 & 2.5 & 30.6 & 36.8 & 68 & 60.7 \\
\hline maps and guides & 6 & 11.8 & 38.9 & 45.6 & 55.1 & 42.6 \\
\hline water equipment & 3.4 & 5.4 & 43.9 & 52.4 & 52.7 & 42.2 \\
\hline skis, snowboards & 11.7 & 22.5 & 53.6 & 54.9 & 34.7 & 22.6 \\
\hline pool & 11.3 & 14.7 & 57.7 & 53 & 31 & 32.4 \\
\hline slides & 17.9 & 17.2 & 47.8 & 45.6 & 34.2 & 37.2 \\
\hline arcade and puzzle games & 12.9 & 22.5 & 55.6 & 56.9 & 31.5 & 20.6 \\
\hline skates & 13.3 & 15.2 & 59.5 & 53.4 & 27.1 & 31.4 \\
\hline playground & 27.6 & 37.3 & 57.7 & 51.9 & 14.7 & 10.8 \\
\hline library & 36.3 & 46.6 & 46.4 & 36.7 & 17.2 & 16.7 \\
\hline
\end{tabular}

Source: Own calculations

1978; Gentry \& Doering 1979; Teaff \& Turpin 1996; Lang et al. 1997). Slight differences in expectations by gender were noticeable, but mostly these were statistically irrelevant. It confirms, for example, the views of Carpio et al. (2008), that tourist market segmentation by demographic characteristics cannot be fully satisfactory.

Students' expectations toward agritourist farm facilities regarding their financial status

Research results were diversified where relations between income per one family member, and tourist preferences and expectations were concerned. For example Keyser (2002) stated that tourist's expectations correspond to the financial situation of households as holiday expenses depend on people's income. O'Leary et al. (1982); however, proved that such a relation does not exist and particular people must accept their social group's conditions.

Data collected from our survey indicates that a weak correlation between net income per member of a student's family and their expectations toward agritourist facilities was observed. Yet, it was an inversely proportional correlation.

Students whose families' net income per family member was the lowest, were characterized by the highest expectations. The average value of significance on Likert's scale for all facilities was around 2.42 for this group. On the other hand, the lowest expectations were characterized by respondents with the highest income. In their case, the average value of significance on Likert's scale amounted to 2.25. Nevertheless, the differences were not large. The average for all the surveyed students was around 2.34 with a standard deviation of around 0.07 .

The differentiation could have been a result of the fact that a possible holiday, outside the place of living, for the worst off students would have been a heavy burden on the home budget. According to them, a relatively big expenditure should assure a comfortable stay. That is why those students expected a higher quality of service in agritourist farms without changing the acceptable, yet relatively high, prices. A possible holiday in different facilities with higher standards would not have been financially available. On the other hand, people with an above average financial status could have been aware that a higher service quality is associated with higher prices. As a result, their expectations toward agritourist facilities were lower.

The biggest differentiation in expectations concerned the access to a kitchen. Students with the highest financial status rated its significance the lowest (from 3.13 in case of medium income up to 3.25 in case of high income) (Fig.4, Tab 3). This was a natural occurrence as students with the highest incomes were more often than others, ready to buy meals outside the agritourist farms.

A significant diversity of expectations could also have been observed in relation to the provision of bicycles. In this case it was of smaller significance to respondents with the highest income (2.54) and greater for the rest of the respondents (from 2.7 in the case of high income, up to 2.9 in the case of low income). A conclusion may be drawn from this, that students with the highest income used their own equipment more often. There were few respondents from this group who claimed in the questionnaire that bicycle sheds were an important element of agritourist farm facilities.

Diversity also occurred in relation to skis and snowboards. In this case; however, their significance was greater for those with very high income (2.17) when compared to the rest of the respondents (from 1.83 in case of medium income up to 1.93 in case of low and high income) (Fig. 4, Tab 3.). This may result from home-grown patterns of spending free time. Families with higher income spend winter holidays in the mountains more often than those with the low income. 
MISCELLANEA GEOGRAPHICA - REGIONAL STUDIES ON DEVELOPMENT

Vol. $19 \cdot$ No. $4 \cdot 2015 \cdot$ pp. 44-55 • ISSN: 2084-6118 • DOI: 10.1515/mgrsd-2015-0023

Table 3. Significance of agritourist farm facilities for students by income differentiation

\begin{tabular}{|c|c|c|c|c|c|c|}
\hline \multirow{3}{*}{ agritourist farm facilities } & \multicolumn{6}{|c|}{ significance by income (\% of respondents) } \\
\hline & \multicolumn{2}{|c|}{ no significance } & \multicolumn{2}{|c|}{ small and medium } & \multicolumn{2}{|c|}{ great and very great } \\
\hline & low & very high & low & very high & low & very high \\
\hline bonfire place & 1.4 & 0.0 & 11.6 & 6.5 & 87.0 & 93.5 \\
\hline access to a kitchen & 3.2 & 8.7 & 16.7 & 26.1 & 80.1 & 65.2 \\
\hline grill & 0.9 & 0.0 & 20.4 & 26.1 & 78.7 & 73.9 \\
\hline bicycles & 1.4 & 4.3 & 29.6 & 43.5 & 69.0 & 52.2 \\
\hline access to the Internet & 5.6 & 6.5 & 26.9 & 37.0 & 67.6 & 56.5 \\
\hline beach equipment & 5.1 & 6.5 & 29.6 & 32.6 & 65.3 & 60.9 \\
\hline garden & 3.7 & 0.0 & 26.9 & 37.0 & 69.4 & 63.0 \\
\hline maps and guides & 6.5 & 10.9 & 38.9 & 39.1 & 54.6 & 50.0 \\
\hline water equipment & 4.6 & 10.9 & 45.4 & 37.0 & 50.0 & 52.2 \\
\hline skis, snowboards & 19.4 & 15.2 & 43.1 & 37.0 & 37.5 & 47.8 \\
\hline pool & 12.5 & 10.9 & 50.9 & 58.7 & 36.6 & 30.4 \\
\hline slides & 13.4 & 23.9 & 50.5 & 43.5 & 36.1 & 32.6 \\
\hline arcade and puzzle games & 12.0 & 21.7 & 54.2 & 56.5 & 33.3 & 21.7 \\
\hline skates & 15.3 & 26.1 & 53.2 & 39.1 & 31.5 & 34.8 \\
\hline playground & 38.4 & 41.3 & 44.0 & 50.0 & 17.6 & 8.7 \\
\hline library & 29.6 & 43.5 & 55.6 & 45.7 & 14.8 & 10.9 \\
\hline
\end{tabular}

Source: own calculations

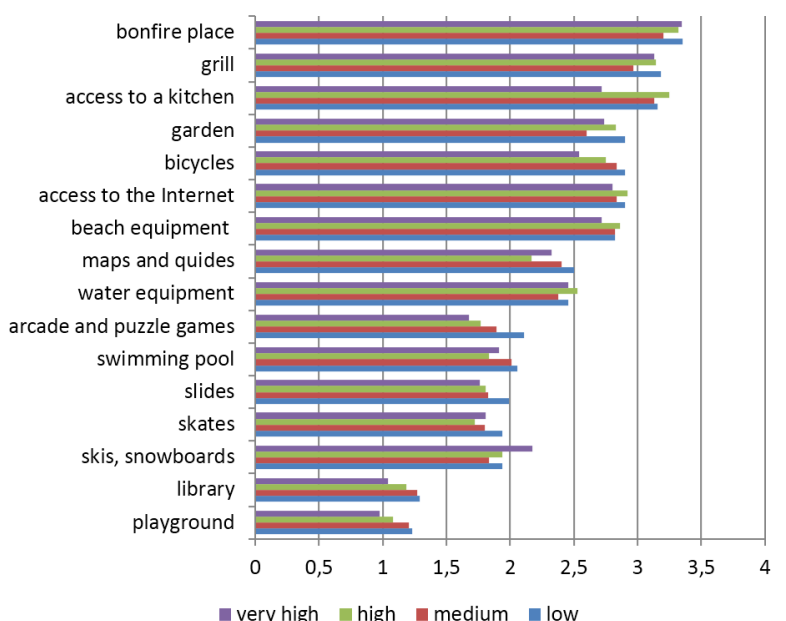

Figure 4. Diversification of expectations toward agritourist farm facilities by net income per family member

Source: Own calculations

Expectations toward the remaining elements of agritourist farm facilities mentioned in the survey were much less diversified regarding students' income.

Therefore, it may be stated that the results rather confirm the theory, known from the literature, that the economic status of tourists does not determine their tourist behaviors and expectations (O'Leary 1982). It should also be underlined that students' income per one family member is not the best characteristic for tourist market segmentation.
Students' expectations toward agritourist farm facilities regarding their place of living

The number of papers regarding tourist market segmentation by place of living (in the city-rural area cross-section) and international comparisons of tourists' behaviors and expectations toward agritourism by this characteristic, is limited. This may result from differing definitions for rural areas (see: Hrušek 2015) and from the diverse mobility of particular countries' inhabitants. Ainley and Smale (2010) claim that it is not the present place of living, but family roots that influence agritourists' behaviors and expectations, as many current inhabitants of cities and rural areas have grown-up in a rural environment and/or have had close contact with a family that lives there. The cited authors suggest that taking into consideration the processes of rural area depopulation and society's increasing departure from agriculture, a new niche in agritourism may appear, based on serving tourists who would be eager to visit their relatives staying in the rural area and to refresh their childhood memories.

The survey conducted indicated that students' places of living affects their expectations toward tourism-related and leisure facilities only slightly. People living in big cities and in rural areas had the highest expectations (average value for all elements on Likert's scale: 2.38 and 2.39 respectively) and inhabitants of small and medium cities, the lowest (2.27 and 2.24 respectively; with the average of all respondents being 2.34 with a standard deviation of 0.08 ). Access to a garden, a grill, bonfire place and beach equipment was of higher importance for people registered in big cities and in rural areas than for others.

It may be concluded that these people, more often than others, preferred passive leisure. It is also worth noting that the importance of the Internet was lower for inhabitants of big cities (2.6 on Likert's scale) than for others (registered in the rural areas: 3.0 , in small cities: 2.86 , in medium cities: 2.84 ). 
Table 4. Significance of agritourist farm facilities for students by place of living

\begin{tabular}{|c|c|c|c|c|c|c|}
\hline \multirow{3}{*}{ agritourist farm facilities } & \multicolumn{6}{|c|}{ significance by place of living ( $\%$ of respondents) } \\
\hline & \multicolumn{2}{|c|}{ no significance } & \multicolumn{2}{|c|}{ small and medium } & \multicolumn{2}{|c|}{ great and very great } \\
\hline & rural area & city & rural area & city & rural area & city \\
\hline bonfire place & 0.6 & 1.0 & 10.4 & 14.6 & 89.1 & 84.4 \\
\hline access to a kitchen & 3.3 & 2.3 & 16.9 & 18.6 & 79.9 & 79.1 \\
\hline grill & 1.2 & 2.0 & 18.0 & 23.6 & 80.8 & 74.4 \\
\hline bicycles & 1.8 & 1.7 & 30.8 & 34.6 & 67.5 & 63.8 \\
\hline access to the Internet & 3.8 & 5.0 & 25.4 & 32.6 & 70.7 & 62.5 \\
\hline beach equipment & 3.3 & 4.0 & 28.4 & 33.6 & 68.3 & 62.5 \\
\hline garden & 3.8 & 6.3 & 32.0 & 28.2 & 64.2 & 65.4 \\
\hline maps and guides & 7.1 & 8.6 & 41.4 & 40.5 & 51.5 & 50.8 \\
\hline water equipment & 4.1 & 4.0 & 45.9 & 47.5 & 50.0 & 48.5 \\
\hline skis, snowboards & 20.1 & 15.0 & 47.6 & 46.5 & 32.2 & 38.5 \\
\hline pool & 12.4 & 12.3 & 56.2 & 56.1 & 31.4 & 31.6 \\
\hline slides & 14.2 & 16.3 & 54.1 & 53.8 & 31.7 & 29.9 \\
\hline arcade and puzzle games & 14.2 & 13.6 & 54.7 & 60.5 & 31.1 & 25.9 \\
\hline skates & 16.3 & 15.6 & 55.6 & 56.5 & 28.1 & 27.9 \\
\hline playground & 40.5 & 38.5 & 42.3 & 44.5 & 17.2 & 16.9 \\
\hline library & 30.5 & 30.9 & 55.9 & 55.8 & 13.6 & 13.3 \\
\hline
\end{tabular}

Source: Own calculations

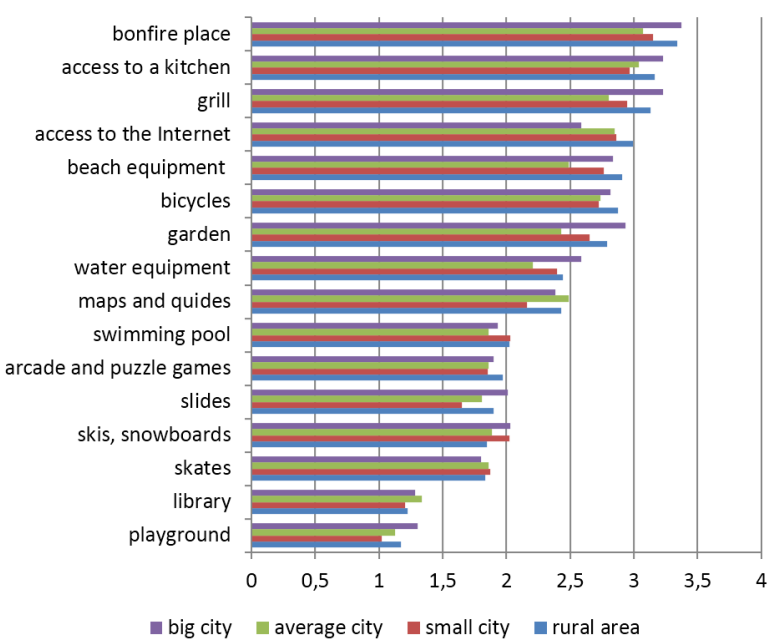

Figure 5. Differentiation of expectations toward agritourist farm facilities by place of living

Source: Own calculations

In the case of the other characteristics any important diversification of students' expectations and their place of living was not observed.

Students' expectations toward agritourist farm facilities regarding their field of studies

In the studies concerning relations between tourist expectations and the socio-demographic and economic characteristics of respondents - characteristics such as age, gender, marital and family status - the level of income or holiday lifestyle are usually used. Aspects regarding tourists' interests are passed over. It is understandable, as problems involving interests are very complex. Tourists usually have many interests, and it is not necessarily possible to include them in a simple qualification. Moreover, a tourist destination chosen by particular persons is usually a result of the fulfilment of their interests. A stay on an agritourist farm is mainly connected with fulfilling the aims of resting. Fulfilment of other interests is of secondary meaning and occurs "by the way". Naturally, trips other than for resting purposes, such as festival participation, during which agritourist farm only counts as an accommodation facility, should be excluded from this type of thinking.

The student's field of study is usually connected with the academic youth's interests. Nevertheless, it is hard to assume that the field of study may influence expectations toward agritourist farm facilities. Our research confirmed this theory.

Similarly, as in the case of characteristics considered before, the field of studies did not constitute a relevant determinant that shapes the respondents expectations toward agritourist farm facilities. Students of Tourism and Recreation were characterized by the highest expectations (value of the significance of all elements on Likert's scale: 2.4 , with an average for all students of 2.38 with a standard deviation of 0.06 ). Administration (2.38), Geography (2.34) and Spatial Planning students (2.32) did not have much lower expectations. The lowest expectations were those of National Security students (2.24).

The provision of maps and tourist guides was characterized by the biggest differentiation in significance for respondents' rest on agritourist farms. They were the most significant, which seems understandable, for respondents studying Geography (2.82 on Likert's scale), and the least important for National Security students (1.98) (Fig. 6). Expectations toward agritourist farm's 
provisioned with a swimming pool were similarly differentiated. Its significance for students' rest was minor (a 1.98 value of significance for all respondents): the biggest was for Administration students (2.24), the smallest for students of Spatial Planning (1.45) (Fig. 7). Similarly low, yet diverse, expectations regarded the access to a playground and a library. Tourism and Recreation students ranked the significance of a playground highest (1.48); Administration students, on the other hand, ranked it lowest (0.95). The library was most important for Geography students (1.59), while being least important for students of Administration (0.95). Diversification was also a characteristic of expectations toward beach equipment availability, which was most significant for Administration students (3.21) and least significant for Spatial Planning students (2.57) (Fig. 6).

Expectations toward the remaining elements were only slightly diversified.

Students' expectations toward agritourist farm facilities regarding their earlier experience with agritourist services usage

According to Larsen (2007) tourist experience should include expectations, perception and memory. A part of tourist experience results from personality characteristics, and part from expectations toward future travels. The cited author suggests that pleasant experiences may have a positive influence on formulating other pleasant experiences. The negative experiences of an agritourist, on the other hand, may end with abandoning this form of leisure or a particular farm (Morgan, Lugosi \& Ritchie 2010).

People who are often a part of the tourist movement usually have precise expectations of each kind of service. It may be presumed that their expectations should be higher than those of people who rarely take part in tourist events.

In light of the conducted research it can be stated that there was no significant difference in students' expectations toward agritourist farm facilities between people who had already used this kind of leisure and those who had not (Fig. 7).

In the case of both analyzed groups, the average value of significance on Likert's scale for all facilities was identical and amounted to 2.34. A relevant diversification of respondents' answers regarding their expectations toward each element of agritourist farm facilities, was not observed.

The results suggest that students' prior experience, or lack of it, in using agritourist farm services does not diversify their expectations in the researched field. It is common knowledge that this kind of leisure is relatively cheap and does not create luxurious accommodation conditions. Therefore, students' expectations, regardless of their experience in the use of agritourist services, are similar.

\section{Conclusions}

The conducted analyses allow for the formulating of the following conclusions:

1. Taking into consideration the facilities, agritourist farms are ready to serve students. According to the research, academic youth expected, most of all, facilities enabling them to have passive leisure and independent meal preparation. A bonfire place, possibility to grill, and access to a kitchen were of the greatest significance to the students. The facilities providing the possibility of active leisure was less significant to them. Bicycles were expected most, while water equipment and horseback riding equipment were less anticipated. Elements that make it possible to do winter sports such as: skis, snowboards, slides and skates, appeared to be of little importance. As research conducted earlier shows (Zawadka 2014) the facilities expected by students is available in the majority of the functioning agritourist farms.

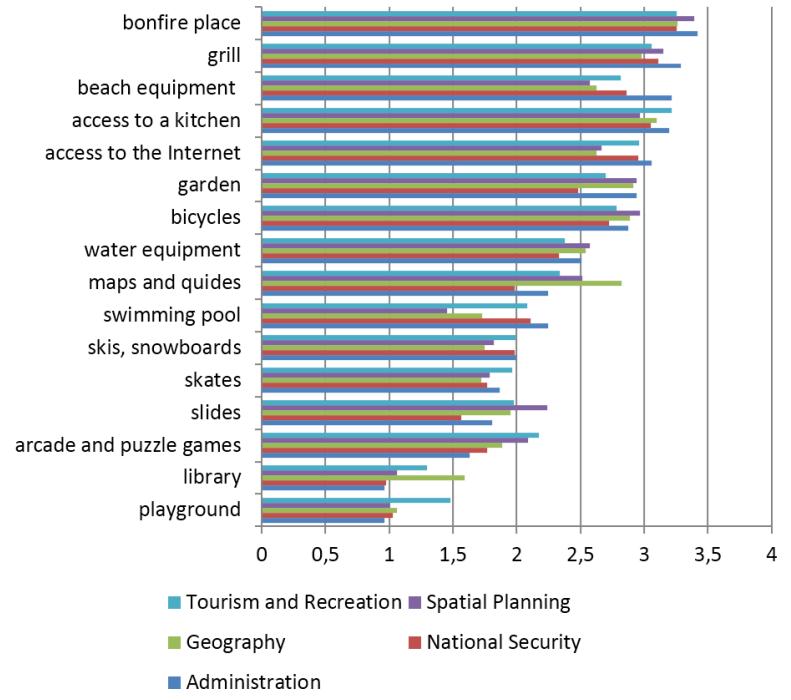

Figure 6. Diversification of expectations toward agritourist farm by field of studies

Source: Own calculations

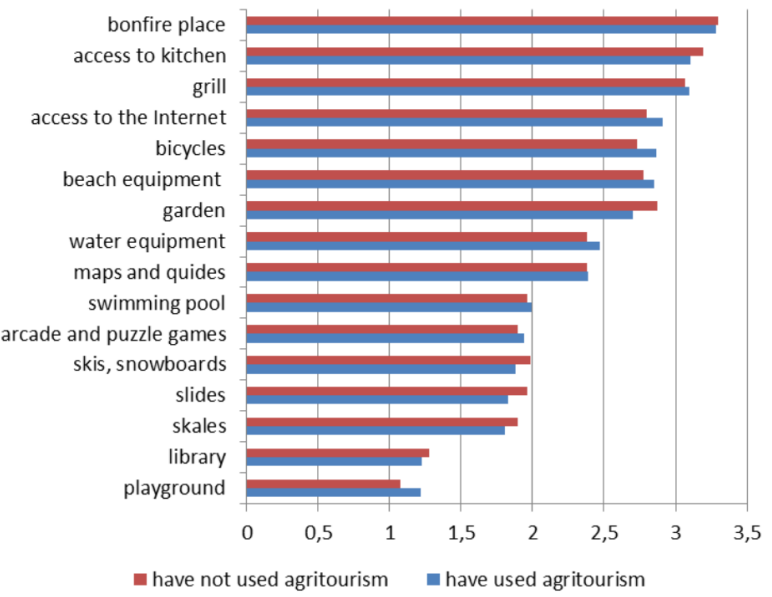

Figure 7. Diversification of expectations toward agritourist farm facilities for students who did or did not use agritourist farms services

Source: Own calculations

2. Gender was not a characteristic differentiating students' expectations toward agritourist farm facilities. It was stated; however, that women's expectations were slightly higher than those of men. This might be a result of the diverse psychophysical characteristics of the genders. Elements enabling passive leisure, for example, a garden or beach equipment were more important to women. Moreover, women rated the significance of maps and tourist guides higher, which was probably an effect of safety needs. Men, in general, have a better sense of direction than women, so they need those pieces of equipment less.

3. A weak correlation between students' expectations toward agritourist farm facilities and their financial status was observed. In general, it was stated that respondents with the lowest income manifested the highest expectations, while the lowest expectations, on the contrary, were shown by those with the highest financial status. This was 
caused by the attitude of those groups toward expenditures connected with tourist service consumption. Expectations toward particular facilities were characterized by different levels of diversification. The highest differentiation applied to the access to a kitchen. Students with low incomes rated its significance higher. Lower income forced those surveyed to prepare meals for themselves. Those academic youth with a high financial status, on the other hand, had the option to use gastronomic services outside the farms. A high diversification regarding the provision of bicycles was also noted. It was least important to people with the highest income as they use their own equipment. This group's highest expectations were; however, in regard to elements enabling them to ski. It resulted from the patterns of spending free time by wealthy people.

4. Place of living did not diversify the students expectations toward agritourist farm facilities. It was noted only that access to a garden, a grill, bonfire place and beach equipment was of higher significance to students from big cities and rural areas than for other groups. Academic youth from big cities searched for elements that they had limited access to within their urbanized living space. Students from rural areas, on the other hand, follow their home patterns of leisure.

5. Field of study was not a characteristic differentiating students' expectations toward agritourist farm facilities. However, it was observed that students of Tourism and Recreation showed slightly higher expectations than the average, which might have been connected to their experience.
6. No difference between the expectations of students that had used agritourist services before and the youth that had never used them before, was observed. This may indicate the above mentioned expectations toward agritourist facilities might as well relate to other tourist accommodation objects which are situated in less urbanized areas (guesthouses, camping, chalets etc.).

7. As research shows (see Zawadka 2012, 2014; Wilk \& Keck-Wilk 2013) students expectations toward agritourist farm facilities were very similar to expectations of an average agritourist. The only differences were the elements that enabled people to eat together in the evenings (a grill, a bonfire place), which were more significant to students than to other agritourist service consumers. This might cause conflicts with other tourists who seek peace and quiet. This is why agritourist farm owners who want to broaden their client target group by including academic youth should situate the bonfire place adequately far away from the rented rooms. Moreover, in the promotional materials they should draw attention to the elements that are of the greatest significance to students, and that were mentioned in this paper, when directing an offer to them.

8. The considered socio-demographic characteristics differentiate academic youths' expectations to a small extent. Psychophysical characteristics, including psychological factors and lifestyle, should be taken into consideration in following studies. A combination of demographic and psychographic characteristics offers a wider base for analysis and may give better end results, allowing market segmentation.

\section{References}

According to Agricultural Census, 2002, United States Summary and State Data, vol.1, Geographic Area Series, part 51.

Agri-tourism in Southern Scotland, 2011, Scottish Natural Heritage Commissioned Report No. 463.

Ainley, S \& Smale, B 2010, 'A profile of Canadian agritoursits and benefit they seek", Journal of Rural and Community Development, vol. 5, 1/2, pp. 57-85.

Alejziak, W 1991, 'Aktywność turystyczna mieszkańców Szwecji na przykładzie populacji sztokholmskiej (wstępny raport z badań)', Folia Turistica, no 2, AWF Kraków, PWN, Kraków, pp. 59-87.

Ashworth, G \& Goodall, B 1988, 'Tourist images: Marketing considerations' in Marketing in the tourism industry, eds B Goodall \& G Ashworth,. The promotion of destination regions, London: Croom-Helm, pp. 213-238.

Balińska, A 2014, 'Aktywność turystyczna mieszkańców wsi w kontekście przemian społeczno-gospodarczych rzeczywisty i potencjalny popyt turystyczny mieszkańców wsi', Roczniki Naukowe Ekonomii Rolnictwa i Rozwoju Obszarów Wiejskich, vol. 101, book 2, pp. 112-122.

Baer-Nawrocka, A \& Poczta, W 2014, 'Przemiany w rolnictwie' in Polska wieś 2014. Raport o stanie wsi, eds I Nurzyńska \& W Poczta, Wyd. Nauk. Scholar, Warszawa, pp. 85-124.

Baloglu, S 1997, 'The relationship between destination images and sociodemographic and trip. Characteristics of international travelers', Journal of Vacation Marketing, vol. 3.3, pp. 221-233.

Blackwell, RD, Miniard, PW \& Engel, JF 2001, Consumer behavior, Fort Worth, TX: Harcourt College Publishers.

Bondoc, I 2009, 'Finding fun in food farming characteristics of U.S.', Agritourism Industry, University of Florida.

Bouĉková, B 2008, 'Definition of agritourism', AgroTourNet 'S Hertogen Bosch. Available from: <www.agrotournet.tringos. eu/files/definition_of_agritourism.ppt>. [12 August 2015].
Brojek, A \& Bochenek, A 2012, 'Sport-tourism interests in the light of all the interests of physical education students in the selected academies in Poland, Sport-tourism interests of the physical education students', Polish Journal Sport Tourism, vol. 19, pp. 68-76.

Broniec, J \& Serocka, K 2005, 'Stan i możliwości rozwoju agroturystyki na terenie Dolnego Śląska' in Turystyka wiejska a rozwój i współpraca regionów, Prace NaukowoDydaktyczne PWSZ w Krośnie, book 15, Krosno, pp. $139-145$

Brown, DM \& Reeder, J 2007, 'Farm based recreation, a statistical profile', A report from the Economic Research Service - USDA.

Campiranon, K 2008, 'Toward and understanding of perceived risk in tourism. Factors influencing crisis vulnerability', Dhurakij Pundit University Journal, issue 66.

Carpio CE, Wohlgenant MK \& Boonsaeng, T 2008, 'The demand for agritourism in the United States', Journal of Agricultural and Resource Economics, vol. 33(2), pp. 254-269.

Catalino AH \& Lizardo, M 2004, 'Agriculture, environmental services and agro-tourism in the Dominican Republic', Journal of Agricultural and Development Economics, vol. 1, no. 1, pp. 87-116.

Cha S, Mc. Cleary KW \& Uysal, M 1995, 'Travel motivations of Japanese overseas travellers: A factor-cluster segmentation approach', Journal of Travel Research, vol. 34.1, pp. 33-39.

Cheng, JS \& Lio, MC 2001, 'A preliminary study on the construction of Taiwanese vacation lifestyle scale a case of the Kenting National Park's Travelers', Journal of Outdoor Recreation Study, vol. 14(3), pp. 57-80.

Chi, ChG, Shahrim, A \& Gursoy, D 2010, 'Examining the relationship between food image And tourists' behavioral intentions'. Available from: <www.eurochrie2010.nl/ publications/15.pdf accessed 19/11/11> [13.August 2015]. 
Cichowska, J 2010, 'Sytuacja ekonomiczna badanych gospodarstw agroturystycznych', Infrastruktura i Ekologia Terenów Wiejskich, no. 2, Komisja Technicznej Infrastruktury Wsi PAN, Oddział w Krakowie, pp. 85-94.

Clarke, J 1999, 'Marketing structures for farm tourism: Beyond the individual provider of rural tourism', Journal of Sustainable Tourism, vil. 7.1, pp. 26-47.

Cunningham, GB \& Sagas, M 2006, 'The role of perceived demographic dissimilarity and interaction in customerservice satisfaction', Journal of Applied Social Psychology, vol. 36 (7), pp.1654-1673.

European competitiveness report 2001, 2001, European Commission, Luxembourg.

Formica, S \& Uysal, M 1998, 'Market segmentation of an international cultural-historical event in Italy', Journal of Travel Research, vol. 36.4, pp. 16-24.

Frenkel, I 2014, 'Ludność wiejska' in Polska wieś 2014. Raport o stanie wsi, eds I Nurzyńska \& W Poczta, Wyd. Nauk. Scholar, Warszawa, pp. 27-84

Gilbert, D 1989, 'Rural tourism and marketing', Tourism Management, vol. 10.1 , pp. 3950

Gentry, JW \& Doering, M 1979, 'Sex role orientation and leisure', Journal of Leisure Research, vol. 11(2), pp. 102-111.

Globalisation and competitiveness: Relevant indicators, 1996, STI Working Papers, no. 5, OECD, Paris.

Gunn, CA 1994, Tourism planning: Basics, concepts, cases, Taylor \& Francis, Washington, DC.

Gurgul, E 2005, Agroturystyka jako element rozwoju i promocji regionu, Wydawnictwa Wydziału Zarządzania Politechniki Częstochowskiej, Częstochowa.

Hartmann, LA \& Cordell, HK 1989,'An overview of the relationship between social and demographic factors outdoor recreation participation, General Technical Report SE-52' in Outdoor Recreation Benchmark 1988, ed AE Watson, pp. 255-274.

Heung, VCS, Qu, H \& Chu, R 2001, 'The relationship between vacation factors and sociodemographic and travelling characteristics: The case of Japanese leisure travelers', Tourism Management, vol. 22, pp. 259-269.

Hoffman, J 1980, 'Problems of access in the study of elites and boards of directors' in Fieldwork Experience: Qualitative Approaches in Social Research, eds W Shafir, R Stebbins \& A Turnowitz, St Martin`s Press, New York, pp. 45-56.

Hall, MA 1973, 'Women and physical recreation: a casual analysis', Presented at the Women and Sport Sympozjum, University of Birmingham.

Hrušek, V 2015, Post-agricultural rural space of the Visegrad Countries: Economies, entrepreneurship and policies, in print.

Jalnik, M 2005, Typologia gospodarstw agroturystycznych jako determinanta rozwoju usług, Wydawnictwo Politechniki Białostockiej, Białystok.

Jefferson, A 1991, 'Demographics, youth and tourism', Tourism Management, vol. 12.1, pp.73-75.

Kamińska, W \& Mularczyk, M 2014, Baza agroturystyczna w świetle oczekiwań młodzieży akademickiej. Wyniki badań ankietowych, in print.

Kastenholz, E, Davis, D \& Paul, G 1999, 'Segmenting tourism in rural areas: The case of North and Central Portugal', Journal of Travel Research, vol. 37.4, pp. 353-363.

Kattiyapornpong, U \& Miller, KE 2009, 'Understanding travel behavior using demographic and socioeconomic variables as travel constraints', Journal of Culture Tourism and Hospitality Research, vol. 3, no 1, pp. 84-94.

Keng, KA \& Cheng, JLL 1999, 'Determining tourist role typologies: An exploratory study of Singapore vacationers', Journal of Travel Research, vol. 37, pp. 382-390.
Keyser, H 2002, Tourism development, Cape Town, Oxford University Press.

Kłodziński, M.1997, Wielofunkcyjny rozwój terenów wiejskich w Polsce i w krajach Unii Europejskiej, Wydawnictwo SGGW, Warszawa

Kryński, Z, Kilar, M \& Józefczyk, B 2006, 'Potencjał turystyczny i uwarunkowania rozwoju agroturystyki w gminie Uście Gorlickie', Zeszyty Naukowe, Ekonomika i Organizacja Rolnictwa, no. 7273, Wyd. Akademii Podlaskiej, Siedlce, pp. 93-102.

Kumbhar, VM 2012, 'Tourist expectations regarding agritourism. Empirical evidences from Ratnagiri and Sindhudurg District of Konkan (Maharashtra)', Online International Interdisciplinary Research Journal, vol. 2, issue 3, pp 8291. Available from: <www.researchgate.net/publication/233760362 Tourists_Expectations_Regarding_Agritourism_Empirical_ Evidences_from_Ratnagiri_and_Sindhudurg_District_of_ Konkan \%28Maharashtra\%29>. [14 August 2015].

Kumbhar ,VM 2010, 'Agro-tourism scope and opportunities for the farmers in Maharashtra', Indiastat, September-October 2009. Available from: <www.ssrn.com/abstract $=1550170>$. [14 August 2015]

Lang, CT, O'Leary, JT \& Morrison, AM 1997, 'Distinguishing the destination choices of pleasure travelers from Taiwan', Journal of Travel \& Tourism Marketing, vol. 6, no.1, pp. 21-40.

Larsen, S 2007, 'Aspects of a psychology of the tourist experience', Scandinavian Journal of Hospitality and Tourism, vol. 7 , issue 1, pp. 7-18.

Latosińska, J \& Ludwicka, D 2010, 'Aktywność turystyczna młodzieży akademickiej na przykładzie wyższych uczelni w Łodzi', Turyzm, vol. 1, pp. 21-28.

Lawson, R 1994, 'Demographic segmentation', in Tourism marketing and management handbook, eds SF Witt \& L Moutinho, London, Prentice Hall, pp. 311-315.

Lubowiecki-Vikuk, AP \& Podgórski, Z 2013, 'Zachowania i preferencje turystyczne młodzieży akademickiej' in Współczesne uwarunkowania i problemy rozwoju turystyki, ed R Pawlusiński, IGiGP, UJ, Kraków, pp.149-158.

Łaciak, J 2013, Aktywność turystyczna mieszkańców Polski w wyjazdach turystycznych w 2012 roku, Warszawa.

Maetzold, J 2002, 'Nature-based tourism \& agritourism trends. Unlimited opportunities'. Available from: <www.kerrcenter.com/ publications/2002_ proceedings/agritourism.pdf>. [12 August 2015].

Maneenetr, T \& Tran ,TH 2014, 'Improving the potential of agricultural areas for development of agrotourism: A case study of Ban Mor Village, Sam Sung District, Khon Kaen province', Mediterranean Journal of Social Sciences, vol. 5 no. 23, pp. 533-539.

Mikos von Rohrscheidt, A 2014, 'Zachowania i preferencje turystów zagranicznych korzystających z usług przewodników w Poznaniu w latach 2011-2013', Studia Oeconomica Posnaniensia, vol. 2, no. 3 (264), pp. 154-178.

Morrison, AM, Braunlich, CG, Cai, LA \& O'Leary, JT 1996,'A profile of the Casino Resort vacationer', Journal of Travel Research, vol. 35,2, pp. 55-61.

Morgan, M, Lugosi, P \& Ritchie, JRB 2010, 'The tourism and leisure experience: Consumer and managerial perspectives', Channel View, Bristol.

Nasers, MS 2009, lowa agritourism consumer profile: Demographics, preferences, and participation levels Theses and Dissertations, Paper 10647. Available from: $<w w w$.lib.dr.iastate.edu/etd/10647 accessed 13/11/11>. [12 August 2015]. 
Nicolau, JL \& Más, FJ 2005, 'Heckit modelling of tourist expenditure: Evidence from Spain', International Journal of Service Industry Management, vol. 16, no.3, pp. 271-293.

Oh, JYJ \& Schuett, MA 2010, 'Exploring expenditure-based segmentation for rural tourism: Overnight stay visitors versus excursionists to fee-fishing sites', Journal of Travel and Tourism Marketing, vol. 27, pp. 31-50.

O`Leary, JT, Napier, TL, Dottavio, FD, Yoesting, D \& Christensen, $\mathrm{J}$ 1982, 'Examining predictor variables used in outdoor recreation planning' in Countryman, Guiding Land Use Management, John Hopkin`s University Press, Baltimore, pp. 140-149.

Ollenburg, C \& Buckley, R 2007, Stated economic and social motivations of Australian farm tourism operators, Journal of Travel Research, vol. 45(4), pp. 444-452.

Nickerson, NP 1996, Foundations of tourism, New Jersey, Prentice Hall.

Ohe, Y 2008, 'Characteristics and issues of rural tourism in Japan' in Sustainable tourism, eds CA Brebbia \& FD Pineda, vol. 3, WIT Press, Ashurst, pp. 305-316.

Ohe, Y \& Ciani, A 2012, 'Accessing demand characteristics of agritourism in Italy', Tourism and Hospitality Management, vol. 18, no. 2, pp. 281-296.

Park, D \& Yoon, Y 2009, Segmentation by motivation in rural tourism: A Korean case study, Tourism Management, vol. 30, pp. 99-108.

Perreault, WD, Darden, DK \& Darden, WR 1977, 'A psychographic classification of vacation life styles', Journal of Leisure Research, vol. 9.1, pp. 208-224.

Plummer ,JT 1974, 'The concept and application of lifestyle segmentation', Journal of Marketing, vol. 38(1), pp. 33-37.

Privitera, D 2010, 'The importance of organic agriculture in tourism rural', Applied Studies in Agribusiness and Commerce, Agroinform Publishing House, Budapest, pp. 59-64.

Rilla, E, Hardesty, SD, Getz, C \& George, HA 2011, 'California agritourism operations and their economic potential are growing', California Agriculture, vol. 65(2), pp. 57-65.

Robinson, JP 1967, 'Time expenditure on sports across ten countries', International Review of Sport Sociology, vol. 2, pp. $67-87$.

Rudnicki, R \& Biczkowski, M 2015, 'Agroturystyka jako forma aktywizacji pozarolniczej działalności gospodarstw rolnych w Polsce - stan, zróżnicowanie przestrzenne oraz wpływ środków PROW 2007-2013' in Turystyka wiejska $i$ agroturystyka - nowe paradygmaty dla XXI wieku, eds W Kamińska \& M Wilk-Grzywna, Studia KPZK PAN, Tom CLXII, Warszawa, pp. 83-108.

Sadowski, A2004, 'Agroturystyka i ekoturystyka jako alternatywne metody zwiększania dochodów rolniczych' in Podlasie - wizja rozwoju, ed AF Bocian, Agencja Wydawniczo Reklamowa Autoreklama, Białystok, pp. 120-131.

Sosnowski, J, Ciepiela, GA \& Jankowski, K 2008, 'Wpływ działalności agroturystycznej na ekonomikę gospodarstw rolnych powiatu wyszkowskiego' in Ekonomiczne i społeczne aspekty rozwoju turystyki wiejskiej, ed I Sikorska-Wolak, Wydawnictwo SGGW Warszawa, pp.107-116.

Speirs, LJ 2003, Agritourism: Market Segmentation Profile of Potential and Practicing Agrotourists, Stellenbosch Univeristy.

Srikatanyoo, N \& Campiranon, K 2008, 'Indentifying needs of agritourists for sustainable tourism development', Working series paper. Available from: <www.anzmac.info/ conference/2008/_Proceedings/PDF/S17_/Srikatanyoo\%20 $\% 26 \% 20$ Campiranon $\% 20$ S $1 \% 20 \mathrm{Pn} \% 20 \mathrm{P} 1 \% 20$.pdf>. [12 August 2015].
Szpilko, D, Gierałtowska, M \& Golubiewska, P 2013, Preferencje turystyczne mieszkańców Białegostoku, Economics and Management, vol. 1/2013, pp.101-114.

Szymańska, A\& Dziedzic, D 2005, 'Conjoint analysis jako metoda analizy preferencji konsumentów', Zeszyty Naukowe AE w Krakowie, no 680, 1, pp. 1-14.

Woodside, AG \& Pitts, RE 1976, 'Effects of consumer lifestyles, demographics and travel activities on foreign and domestic travel behavior', Journal of Travel Research, vol. 14, BIS.

Teaff, JD \& Turpin, T 1996, 'Travel and elderly', Parks and Recreation, vol. 31(6), pp. 16-19.

Tew, C \& Barbieri, C 2012, The perceived benefits of agritourism: The providers perspective, Tourism Management, vol. 33, issue 1, Elsevier Ltd, pp. 215-224.

Unkle, MB 1981, 'Psychical recreation partycipation of females and males during the adult life cycle', Leisure Sciences, vol. $4(1)$, p. $1-27$

Walesiak, M 2000, 'Segmentacja rynku. Kryteria i metody' in Przestrzenno-czasowe modelowanie $i$ prognozowanie zjawisk gospodarczych, ed A. Zeliaś, Wydawnictwo AE Kraków, pp. 191-201.

Wang, Y, Rompf, P, Severt, D \& Peerapatdit, N 2006, Examining and identifying the determinants of travel expenditure patterns, International Journal of Tourism Research, vol. 8(5), pp. 333-346.

Wilk, I \& Keck-Wilk, M 2013, 'Oczekiwania turystów dotyczące oferty gospodarstw agroturystycznych', Journal of Agribusiness and Rural Development, vol. 2(28), pp. 243250.

Wilson, L 2007, 'The family farm business? Insights into family, business and ownership dimensions of open-farms', Leisure Studies, vol. 26 (3), pp. 357-374.

Wiśniewska, A 2008, 'Dochodowość usług agroturystycznych w gospodarstwach kaszubskiej gminy Brusy', Słupskie Prace Geograficzne, vol. 5, pp. 65-73.

Witt, PA \& Goodale, TL 1981, 'The relationship between barriers to leisure enjoyment and family stages', Leisure Sciences, vol. 4, pp. 29-49.

Woźniak, M \& Kuźniar, W 2000, 'Znaczenie agroturystyki w ożywieniu gospodarczym obszarów górskich (na przykładzie Podkarpacia)' in Turystyka wiejska w perspektywie europejskiej, Materiały konferencyjne, KCDRRiOW Odział w Krakowie, Kraków, pp. 149-160.

Vanhove, N 1994, 'Market segmentation' in Tourism marketing and management handbook, eds SF Witt \& L Moutinho, London, Prentice Hall, pp. 305-310.

Zawadka, J 2012, Preferencje turystów dotyczące wypoczynku w gospodarstwach agroturystycznych na Lubelszczyźnie, Zeszyty Naukowe Uniwersytetu Szczecińskiego, no. 699, Szczecin, pp. 167-179.

Zawadka, J 2014, 'Zachowania i oczekiwania turystyczne osób wypoczywających na wsi w kontekście infrastruktury okołoturystycznej' in Agrotravel 2014, ed C Jastrzębski, ROT, Kielce, WSWPiNM, Kielce.

Zins, AH 1998, 'Leisure traveler choice models of theme hotels using psychographics', Journal of Travel Research, vol. 36(4), pp. 315.

Zoto, S, Qirici, E \& Polena, E 2013, Agrotourism - a sustainable development for rural area of Korca, European Academic Research, vol. 1(2), pp. 209-223.

Zuzanek, J 1978, 'Social differences in leisure behaviour: Measurement and interpretation', Leisure Sciences, vol. 1(3), pp. 271-293. 